\title{
Effects of ensiling density on nutritive value of maize and sorghum silages
}

\author{
Ekin Sucu ${ }^{1}$, Hatice Kalkan ${ }^{2}$, Onder Canbolat ${ }^{1}$, Ismail Filya ${ }^{1}$
}

\author{
${ }^{1}$ Uludag University, Faculty of Agriculture, Department of Animal Science, Bursa, Turkey. \\ ${ }^{2}$ Istanbul Directorate of Provincial Food Agriculture and Livestock, Istanbul, Turkey
}

\begin{abstract}
Studies were conducted to determine the effects of different ensiling densities on fermentation, aerobic stability, and nutritive value of maize and sorghum silages. Maize and sorghum were harvested at dough (363 g/kg) and milk stages $(275 \mathrm{~g} / \mathrm{kg})$, respectively. Herbages were chopped approximately $1.5 \mathrm{~cm}$ after harvest and then ensiled in mini silos at high and low-bulk densities for 8.5 weeks. Different bulk densities were achieved by ensiling different weights of herbage in the fixed-volume mini silos (1.5-L anaerobic jars, Weck, Germany). The obtained dry matter (DM) densities were 168 and $216 \mathrm{~kg}$ of $\mathrm{DM} / \mathrm{m}^{3}$ for maize forage and 132 and $178 \mathrm{~kg}$ of $\mathrm{DM} / \mathrm{m}^{3}$ for sorghum forage. Fermentation kinetics, the rate of aerobic deterioration upon aerobic exposure, and nutrient digestibility were followed during the periods of ensiling (on days 2, 4, 8, 15, and 60). In all cases, increased packing density resulted in silages with lower acetate content, ammonium $\mathrm{N}$ levels, and fermentation losses, but lactate content did not differ. Butyrate was detected in appreciable amounts only in sorghum silage. Propionate was not detected in any silage. Tightly packed silages remained stable upon exposure to air. Tight packing increases the digestibly of nutrients and improves the energy content of silages. These data show that high density limits air infiltration and reduces the oxidation loss during storage and feed-out. As a consequence, more dry matter is recovered and more energy is preserved.
\end{abstract}

Key Words: cereals, nutritional profile, packing density, silage

\section{Introduction}

In the last decade, the cost of animal production has increased, while the income from milk and meat products have not increased as quickly. This has created the need for animal production to find methods that are more efficient and profitable. One of the most effective methods is producing high-quality forages and using more forage in the diet of animals. Maize and sorghum are the main silages for feeding cattle (Wilkinson and Toivonen, 2003). The most important factor that affects the quality of silage is the ability to pack the silage to control and maintain anaerobic conditions (McDonald et al., 1991). This is achieved by packing silage at a higher density. Packing silage tightly minimizes excessive air, which can result in aerobic respiration and heat (Muck et al., 2004; Savoie et al., 2004). Heat can cause the loss of digestible nutrients and can increase the production of mold spores and mycotoxins (McDonald et al., 1991; Charley, 2008). This was similar

Received May 20, 2016 and accepted August 1, 2016.

Corresponding author: ekins@uludag.edu.tr

http://dx.doi.org/10.1590/S1806-92902016001000003

Copyright (C) 2016 Sociedade Brasileira de Zootecnia. This is an Open Access article distributed under the terms of the Creative Commons Attribution License (http://creativecommons.org/licenses/by/4.0/), which permits unrestricted use, distribution, and reproduction in any medium, provided the original work is properly cited. to the research of Kung $\operatorname{Jr}$ (2010), who stated that lower packing density slowed down ensiling fermentation and aided the level of yeasts produced in the silage, which were found upon opening. It has been suggested that air infusion during storage and feed-out in commercial scale maize silage can contribute to clostridial growth in the peripheral areas of the silo (Borreani and Tabacco, 2009). Ruppel et al. (1995) found that the packing density negatively affected storage losses. Their findings included using a model for a six-month period and they found that losses decreased from 20 to $10 \%$ when packing was increased from 160 to $320 \mathrm{~kg} \mathrm{DM} / \mathrm{m}^{3}$. Another important factor affected by density is the maintenance and preservation of nutrients between the time of opening the silo and the time of using the silage as feed (Johnson et al., 2002; Wilkinson and Davies, 2013). Deteriorated silages cause a serious risk to the quality and safety of animal products and to animal health (Driehuis and Oude Elferink, 2000).

Under our conditions within the Mediterranean climate, two effects would be of greatest interest: a reduction of in-silo losses by an optimized fermentation process and a reduction of losses after the opening of the silo by improving the aerobic stability. Both types of losses are closely correlated to the concentration of oxygen present in the silo, which promotes unwanted microbes. There is little published information about the initial packing density effects on silage quality. Therefore, the objective of this 
study was to investigate the effects of different ensiling densities on fermentation, aerobic stability, and nutritive value of maize and sorghum silages.

\section{Material and Methods}

Silages were prepared from maize (Zea mays L.) and sorghum (Sorghum bicolor L.) and grown in the same years at the Agricultural Experimental Station (40 $\left.14^{\prime} \mathrm{N}, 28^{\circ} 50^{\prime} \mathrm{E}\right)$. Whole-crop maize and sorghum were cut at the dough $(363 \mathrm{~g} / \mathrm{kg})$ and milk stages $(275 \mathrm{~g} / \mathrm{kg})$, respectively. The forages were chopped $(1.5 \mathrm{~cm})$ with a laboratory chopper (Fimaks, Turkey). Three representative samples of fresh chopped forages were collected and frozen for subsequent analysis. Different bulk densities were achieved by ensiling different weight of herbage in the fixed-volume mini silos (1.5-L anaerobic jars, Weck, Germany). To achieve two different bulk densities for maize forage, jars were filled with 1050 and $1350 \mathrm{~g}$ (wet weight) of chopped maize, without a headspace. The obtained dry matter (DM) densities were 168 and $216 \mathrm{~kg}$ of DM/m $/ \mathrm{m}^{3}$ for maize forage. To achieve two different bulk densities for sorghum forage, jars were filled with 1100 and $1450 \mathrm{~g}$ (wet weight) of chopped sorghum, without a headspace. The obtained DM densities were 132 and $178 \mathrm{~kg}$ of $\mathrm{DM} / \mathrm{m}^{3}$ for sorghum forage. The openings of the mini silos were performed in a five-day temporal series on days 2, 4, 8, 15, and 60 after filling. There were 60 jars (two forages $\times$ five days $\times$ two ensiling density $\times$ three parallels) and they were stored at an ambient temperature of $25-28^{\circ} \mathrm{C}$. Ensiled forages (on days after ensiling, three jars per treatment for each time) were sampled for further analysis.

Chemical analyses of fresh forage and silages were performed in triplicate and presented on DM basis. The silage $\mathrm{pH}$ was measured directly from the silage juice using a pH meter (Sartorius PB-20, Germany). Fresh forages and silage samples were dried at $60{ }^{\circ} \mathrm{C}$ for DM determination (AOAC, 1990). Dry matter content of the silages was corrected $\left(\mathrm{DM}_{\mathrm{cor}}\right)$ for the loss of volatile substances during drying through the following equation (Weißbach, 2009): $\mathrm{DM}_{\text {cor }}=\mathrm{DM}+0.95 \times$ sum of fatty acids $(\mathrm{C} 2-\mathrm{C} 6)+0.08$ $\times$ lactic acid $+0.77 \times 1,2$ propanediol $+1.00 \times$ other alcohols (C2-C6 including butanediol) [g/kg]. Fresh forage and silages were analyzed for crude protein (CP) and ash according to AOAC (1990). The neutral detergent fiber (NDF) and acid detergent fiber (ADF) were determined using the sequential analysis scheme of Van Soest et al. (1991). Wet samples stored at $-20^{\circ} \mathrm{C}$ were extracted for $3 \mathrm{~min}$ in a blender in water or in ethyl acetate (1:9) for watersoluble carbohydrates (WSC) and analysis of fermentation products. The WSC were determined as described by
Dubois et al. (1956). Lactic acid was determined by the procedures of Barker and Summerson (1941). The volatile fatty acids (VFA) and alcohol concentrations were analyzed using a gas chromatograph with a capillary column (over a temperature range of $45-230^{\circ} \mathrm{C}$ ). Ammonia-N was determined using a Kjeltech auto analyzer (Gerhardt, Germany). Microbiological analyses of fresh forage and silages were presented on fresh and wet silage basis. Microbiological evaluation included enumeration of lactobacilli on pourplate rogosa agar (Oxoid CM627, Oxoid, Basingstoke, U.K.) and yeast and mold on spread-plate malt extract agar (Difco, Detroit, MI), acidified with lactic acid to $\mathrm{pH}$ 4.0. Plates were incubated for $3 \mathrm{~d}$ at $30^{\circ} \mathrm{C}$. All microbiological data were transformed into $\log _{10}$.

At the end of the ensiling period ( $\mathrm{d} 60$ ), the silages were subjected to an aerobic stability test at room temperature $\left(22{ }^{\circ} \mathrm{C}\right)$, which lasted $5 \mathrm{~d}$, in a "polyethylene terephthalate (P.E.T.) bottle" system developed by Ashbell et al. (1991). The system was constructed from recycled soft drink bottles (polyethylene terephthalate) in two parts: the upper part (1-L) was filled with $250 \mathrm{~g}$ (wet weight) of loosely packed silage and the lower part with $100 \mathrm{~mL}$ of $20 \% \mathrm{KOH}$. Gas was exchanged through 1-cm holes in the lid of the upper part to the lower part. The $\mathrm{CO}_{2}$ produced during aerobic exposure was absorbed in the base and determined by titration with $1 \mathrm{~N} \mathrm{HCl}$. In addition, silage $\mathrm{pH}$ was measured and yeast and mold analyses were performed as the indicators of aerobic spoilage as well. The $\mathrm{pH}$ and yeast and mold analyses were determined by the previously explained analysis methods. Analyses were carried out in the silage samples after $5 \mathrm{~d}$ of exposure to air.

In vitro digestible $\mathrm{DM}(\mathrm{dDM})$ and digestible neutral detergent fiber (dNDF) were determined according to Holden (1999) for each silage using a DaisyII Incubator (Ankom ${ }^{\circledR}$ Technology Corp., Fairport, NY, USA) and a fiber analyzer (ANKOM Technology Corporation).

Digestible organic matter (dOM) and metabolizable energy (ME) values in silages were calculated from the following equation (Menke and Steingass, 1988): dOM, $(\%)=0.9042 \times \mathrm{GP}+0.0492 \times \mathrm{CP}+0.0387 \times \mathrm{CA}+16.49$ and ME, MJ kg DM $=2.20+\mathrm{GP} \times 0.14+\mathrm{CP} \times 0.006+\mathrm{EE} 2$ $\times 0.0003$, in which GP is the amount of net gas production at $24 \mathrm{~h}(0.2 \mathrm{~g} \mathrm{DM})$ and $\mathrm{CP}, \mathrm{CA}$, and $\mathrm{EE}$ are crude protein, crude ash, and ether extract (\% DM), respectively.

The data obtained from silage quality were analyzed as a completely randomized design with three replications and subjected to analysis of variance by the GLM procedure of SAS (Statistical Analysis System, version 6.0). Differences among means were tested using Tukey's test and significance was declared at $\mathrm{P}<0.05$. 


\section{Results}

The fresh maize had $363 \mathrm{~g} \mathrm{DM} / \mathrm{kg}$ with a $\mathrm{pH}$ value of 5.92 (Table 1). The NDF and ADF contents of fresh maize were 542 and $333 \mathrm{~g} / \mathrm{kg}$ DM, respectively. Pre-ensiled maize had adequate levels of WSC (66 g/kg DM), but was relatively low in protein content $(70 \mathrm{~g} / \mathrm{kg} \mathrm{DM})$. The fresh sorghum had $270 \mathrm{~g} \mathrm{DM} / \mathrm{kg}$ with a $\mathrm{pH}$ value of 6.05 . The NDF and ADF contents of fresh sorghum were 578 and $360 \mathrm{~g} / \mathrm{kg} \mathrm{DM}$, respectively. Pre-ensiled sorghum had high levels of WSC (33 g/ $\mathrm{kg} \mathrm{DM})$, but contained low levels of protein $(51 \mathrm{~g} / \mathrm{kg} \mathrm{DM})$. The epiphytic lactobacilli and yeast counts were high in both herbages, each being 10-log cfu/g.

Both ensiling density and the day of fermentation affected $(\mathrm{P}<0.05)$ the chemical composition of silages (Table 2). These effects were stronger $(\mathrm{P}<0.05)$ at the initial stage of fermentation. The DM recovery was higher $(\mathrm{P}=0.06)$ in tightly packed silages than in loosely packed silages. Loosely packed sorghum silages had higher $(\mathrm{P}<0.05)$ fermentation losses than maize silages. The fiber fractions and protein content of silages were unaffected $(\mathrm{P}>0.05)$ by the packing density.

Maize and sorghum silages appeared to have fermented normally, as indicated by the final $\mathrm{pH}$ levels of 3.8 and 3.6 and fermentation acid levels of 83 to $72 \mathrm{~g} / \mathrm{kg} \mathrm{DM}$, respectively (Table 3). Both ensiling density and the day of fermentation exerted a substantial influence on the fermentation profile of silages $(\mathrm{P}<0.05)$. Thus, the difference between the higher packing densities was much greater for initial stages of fermentation than the latter stages of fermentation for both types of silages $(\mathrm{P}<0.05)$. Within the first week of fermentation, nearly $80 \%$ of the

Table 1 - Chemical composition and epiphytic lactobacilli of pre-ensiled maize and sorghum

\begin{tabular}{lcc}
\hline & Maize & Sorghum \\
\hline Dry matter (g/kg) $_{\mathrm{DM}_{\text {cor }}}$ & $363.3 \pm 2.22$ & $275.1 \pm 1.32$ \\
$\mathrm{pH}$ & $370.9 \pm 1.60$ & $276.4 \pm 5.46$ \\
Crude protein (g/kg DM) & $5.92 \pm 0.11$ & $6.05 \pm 0.13$ \\
Ash (g/kg DM) & $73.4 \pm 1.65$ & $50.6 \pm 3.11$ \\
Neutral detergent fiber (g/kg DM) & $53.8 \pm 0.99$ & $50.0 \pm 0.69$ \\
Acid detergent fiber (g/kg DM) & $577.6 \pm 20.05$ & $642.1 \pm 40.7$ \\
Hemicellulose ${ }^{1}$ (g/kg DM) & $332.6 \pm 9.32$ & $359.3 \pm 60.3$ \\
Water soluble carbohydrates (g/kg DM) & $245 \pm 24.12$ & $282.2 \pm 46.1$ \\
Lactate & $15.28 \pm 0.96$ & $32.6 \pm 3.41$ \\
Acetate & $6.67 \pm 0.21$ & $0.39 \pm 0.32$ \\
Butyrate & 0 & $0.03 \pm 0.04$ \\
Alcohols & 0 & $0.12 \pm 0.06$ \\
NH $-\mathrm{N}$ (g/kg TN) & $5.33 \pm 0.61$ & $4.22 \pm 0.22$ \\
Lactobacilli (log cfu/g DM) & 9.71 & 10.0 \\
Yeast & 10 & 9.65 \\
\hline
\end{tabular}

DM - dry matter; $\mathrm{DM}_{\text {cor }}$ - dry matter corrected for loss of volatiles; NDF - neutral detergent fiber; $\mathrm{ADF}$ - acid detergent fiber; $\mathrm{NH}_{3}-\mathrm{N}$ - ammonium nitrogen; TN - total nitrogen; cfu - colony-forming units.

${ }^{1}$ Hemicellulose calculated as the difference between NDF and ADF. total carbohydrates available were metabolized in maize and sorghum silages $(\mathrm{P}<0.05)$. As fermentation progressed, the concentration of lactic acid increased and the concentration of acetic acid decreased $(\mathrm{P}<0.05)$. Overall, the level of packing density did not influence $(\mathrm{P}>0.05)$ the lactate production, but influenced the acetate and ammonium-N levels $(\mathrm{P}<0.05)$. Lower levels were obtained in tightly packed silages $(\mathrm{P}<0.05)$. The accumulation of butyric acid was not seen in maize silages. However, a very small amount was seen in sorghum silages and were lower in tightly packed silages $(\mathrm{P}<0.05)$. The concentrations of alcohols were decreased with the fermentation progress and lower levels were obtained in tightly packed silages $(\mathrm{P}<0.05)$.

Two weeks after the beginning of fermentation, the amount of lactobacilli was higher than after eight weeks of fermentation (Table 4). The yeast count after two weeks was higher, but at eight weeks it was negligible. The total number of yeasts was $50 \%$ higher in the loosely packed silages than in the tightly packed. The yeast counts were higher in the sorghum silages than in the maize silage. No mold growth was detected.

The $\mathrm{pH}$ and $\mathrm{CO}_{2}$ production within five days of air exposure was higher $(\mathrm{P}<0.05)$ in loosely packed silages than in tightly packed silages (Table 5). The most significant improvement in aerobic stability was seen in the silages with the highest packing density because of the lower yeast activity $(\mathrm{P}<0.05)$. Loosely packed sorghum silages had higher $\mathrm{CO}_{2}$ production and yeast counts than maize silages. Regardless of the packing rate, no mold growth was observed in the silages. Visible molds were low in both types of silages that were exposed to air, each being one.

The level of packing density affected $(\mathrm{P}<0.05)$ the content of digestible DM, NDF, and OM and the calculated ME content of silages (Table 6). These parameters were higher in the tightly packed vs. the loosely packed silages $(\mathrm{P}<0.05)$. Tightly packed maize silage had $21 \%$ higher OM digestibility and $31.5 \%$ higher energy content than sorghum silages.

\section{Discussion}

One of the most important factors influencing preservation characteristics and nutritive value of forages is the density of forage mass and the levels of air-filled porosity in the silo (McDonald et al., 1991). Thus, the ensiling density is important in the influence on the fermentation course and final fermentation quality as well as animal performance.

In this study, factors affecting the pattern of fermentation in the silo are considered and the effects 
Table 2 - Chemical composition of maize and sorghum silages (g/kg DM) at two ensiling densities

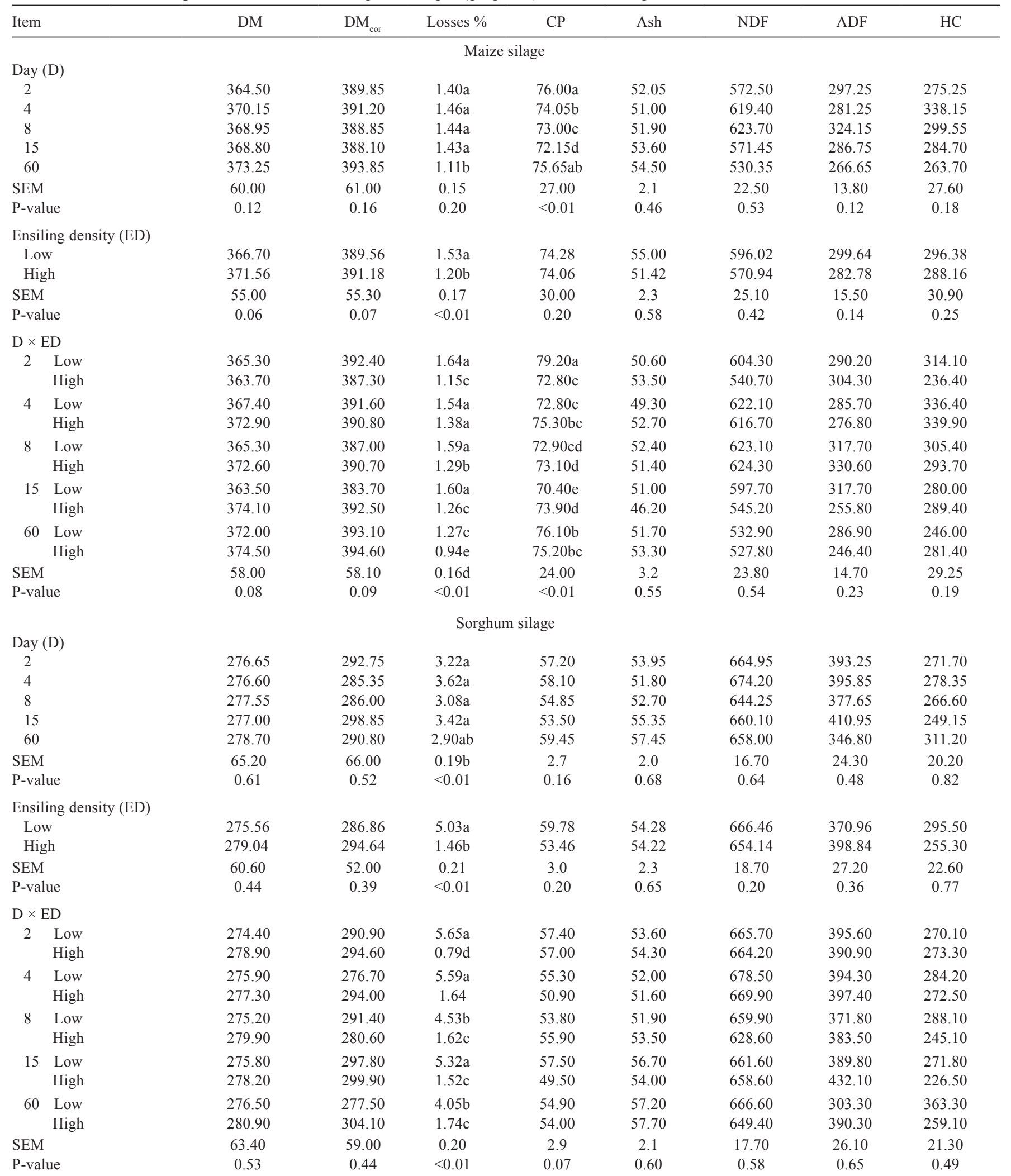

DM - dry matter; $\mathrm{DM}_{\text {cor }}$ - dry matter corrected for loss of volatiles; CP - crude protein; NDF - neutral detergent fiber; ADF - acid detergent fiber; HC - hemicellulose calculated as the difference between NDF and ADF; SEM - standard error of the mean.

Means in the same column with different letters differ significantly $(\mathrm{P}<0.05)$. 
Table 3 - Fermentation metabolites of maize and sorghum silages (g/kg DM) at two ensiling densities

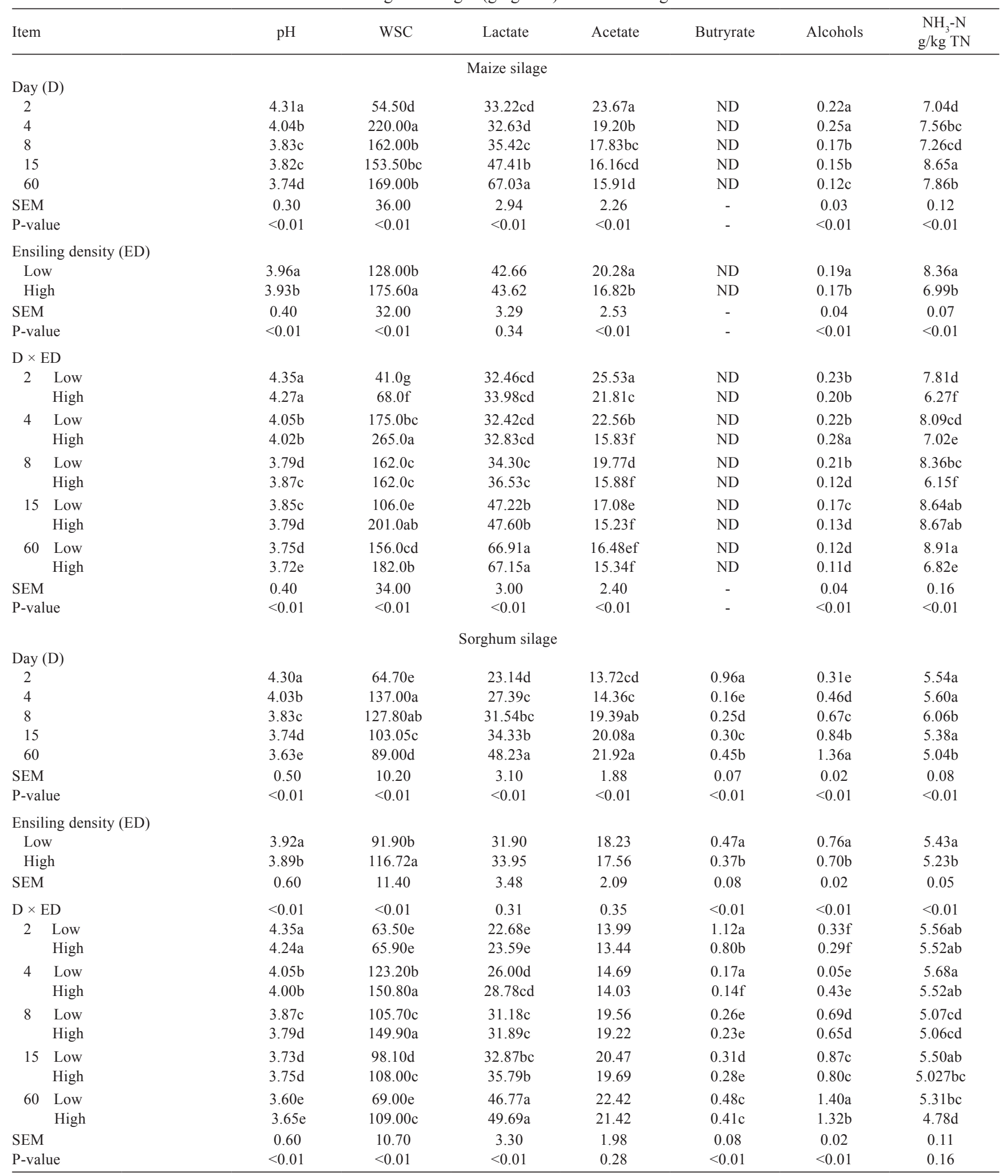

WSC - water soluble carbohydrates; ND - not detected; $\mathrm{NH}_{3}-\mathrm{N}$ - ammonium nitrogen; TN - total nitrogen; SEM - standard error of the mean. Means in the same column with different letters differ significantly $(\mathrm{P}<0.05)$. 
of ensiling density on silage quality are illustrated. As expected, ensiling maize and sorghum benefit the maintenance of silage protein content close to that of the fresh forage. The reduction in ammonia-N of tightly packed silages is indicative of lower proteolytic activity, which may have resulted in improved protein-N utilization in the rumen. This hypothesis for improvement in protein-N utilization of well-preserved silages has been proposed previously. Sharp et al. (1994) investigated the digestion of well-preserved silages with 16-month-old Jersey

Table 4 - Microbiological composition of maize and sorghum silages $(\log \mathrm{cfu} / \mathrm{g})$ at two ensiling densities

\begin{tabular}{|c|c|c|c|}
\hline \multicolumn{2}{|l|}{ Item } & Lactobacilli & Yeasts \\
\hline & & Maize sila & \\
\hline \multicolumn{4}{|c|}{ Day (D) } \\
\hline \multicolumn{2}{|c|}{2} & 11.10 & 8.65 \\
\hline \multicolumn{2}{|l|}{4} & 10.95 & 6.95 \\
\hline \multicolumn{2}{|l|}{8} & 10.45 & 6.10 \\
\hline \multicolumn{2}{|l|}{15} & 9.60 & 4.50 \\
\hline \multicolumn{2}{|l|}{60} & 7.65 & 3.85 \\
\hline \multicolumn{4}{|c|}{ Ensiling density (ED) } \\
\hline \multicolumn{2}{|c|}{ Low } & 9.79 & 6.06 \\
\hline \multicolumn{2}{|c|}{ High } & 10.10 & 5.96 \\
\hline \multicolumn{4}{|c|}{$\mathrm{D} \times \mathrm{ED}$} \\
\hline \multirow[t]{2}{*}{2} & Low & 11.00 & 8.40 \\
\hline & High & 11.20 & 8.88 \\
\hline \multirow[t]{2}{*}{4} & Low & 10.70 & 7.19 \\
\hline & High & 11.20 & 6.74 \\
\hline \multirow[t]{2}{*}{8} & Low & 10.50 & 6.00 \\
\hline & High & 10.40 & 6.18 \\
\hline \multirow[t]{2}{*}{15} & Low & 9.45 & 4.65 \\
\hline & High & 9.74 & 4.30 \\
\hline \multirow[t]{2}{*}{60} & Low & 7.30 & 4.00 \\
\hline & High & 7.98 & 3.70 \\
\hline \multirow{2}{*}{\multicolumn{4}{|c|}{ Sorghum silage }} \\
\hline & & & \\
\hline \multicolumn{2}{|l|}{2} & 10.82 & 9.27 \\
\hline \multicolumn{2}{|l|}{4} & 10.60 & 6.05 \\
\hline \multicolumn{2}{|l|}{8} & 10.55 & 5.20 \\
\hline \multicolumn{2}{|l|}{15} & 10.30 & 5.15 \\
\hline \multicolumn{2}{|l|}{60} & 8.40 & 4.95 \\
\hline \multicolumn{4}{|c|}{ Ensiling density (ED) } \\
\hline \multicolumn{2}{|c|}{ Low } & 9.97 & 6.44 \\
\hline \multicolumn{2}{|c|}{ High } & 10.31 & 5.82 \\
\hline \multicolumn{4}{|c|}{$\mathrm{D} \times \mathrm{ED}$} \\
\hline 2 & Low & 10.74 & 9.48 \\
\hline & High & 10.90 & 9.06 \\
\hline 4 & Low & 10.54 & 6.22 \\
\hline & High & 10.73 & 5.85 \\
\hline 8 & Low & 10.51 & 5.27 \\
\hline & High & 10.64 & 5.08 \\
\hline 15 & Low & 10.11 & 5.66 \\
\hline & High & 10.47 & 4.60 \\
\hline 60 & Low & 7.95 & 5.46 \\
\hline & High & 8.80 & 4.40 \\
\hline
\end{tabular}

cfu - colony-forming units.

Microbiological analysis was performed on a single sample each time. Therefore, no statistical analyses are available. heifers and reported a 33\% improvement in efficiency of microbial protein synthesis. The overall drop in $\mathrm{pH}$ values reflected the production of acidic metabolites. The decrease of acetic acid in silages in the later stages of fermentation is the result of the achievement of anaerobic conditions in both types of silages (McDonald et al., 1991). However, the final WSC and the fermentation acid concentrations were, respectively, 89 and $15 \%$ higher in the maize silages than in the sorghum silages. These differences can be explained by the maturities (Tabacco et al., 2009). Differences in yeast populations, resulting from aeration (because of the different consolidation rates), become less apparent as the fermentation progressed. Mold that was present on the fresh maize and sorghum was not similarly active on the corresponding silages. These results would suggest that the fermentation pattern was predominantly homolactic (McDonald et al., 1991; Gerlach et al., 2013) and this led to lower fermentation losses, especially in tightly packed silages (Ruppel, 1992; Losand, 2003; Savage et al., 2015).

Table 5 - Results of aerobic stability test ( 5 d) for maize and sorghum silages at two ensiling densities after a $60 \mathrm{~d}$ storage period

\begin{tabular}{lcccccc}
\hline Forage & $\begin{array}{c}\text { Ensiling } \\
\text { density }\end{array}$ & $\mathrm{pH}$ & $\begin{array}{c}\mathrm{CO}_{2} \\
(\mathrm{~g} / \mathrm{kg} \mathrm{DM})\end{array}$ & $\begin{array}{c}\text { Yeast } \\
\left(\log _{10} \mathrm{cfu} / \mathrm{g}\right)\end{array}$ & $\begin{array}{c}\text { Mold } \\
\text { molding }^{1}\end{array}$ \\
\hline Maize silage & Low & $5.82 \mathrm{a}$ & $7.79 \mathrm{a}$ & 8.22 & 0 & 1 \\
& High & $4.82 \mathrm{~b}$ & $5.89 \mathrm{~b}$ & 6.20 & 0 & 1 \\
& SEM & 0.02 & 1.01 & - & & \\
Sorghum silage & Low & $5.69 \mathrm{a}$ & $49.90 \mathrm{a}$ & 10.40 & 0 & 1 \\
& High & $4.65 \mathrm{~b}$ & $8.57 \mathrm{~b}$ & 9.28 & 0 & 1 \\
& SEM & 0.03 & 4.25 & - & - & - \\
\hline
\end{tabular}

DM - dry matter; log - logarithm of the numbers; cfu - colony-forming units; SEM standard error of the mean.

Microbiological analysis was performed on a single sample each time. Therefore, no statistical analyses are available.

${ }^{1}$ Visual appraisal is expressed using a scale of 1 to 5 , in which $1=$ good quality silage with no visible molding; 2 = a few small mold spots; $3=$ scattered mold spots; 4 = silage with partially covered molds, lumpy silage; 5 = completely moldcovered samples, unpleasant odor, and silage particles sticking together.

Means in the same column with different letters differ significantly $(\mathrm{P}<0.05)$.

Table 6 - In vitro rumen digestible dry matter, fiber and organic matter, and calculated metabolizable energy values for maize and sorghum silages at two ensiling densities after a 60 d storage period

\begin{tabular}{lccccc}
\hline Forage & $\begin{array}{c}\text { Ensiling } \\
\text { density }\end{array}$ & dDM & dNDF & dOM & $\begin{array}{c}\text { ME } \\
\text { MJ/kg DM }\end{array}$ \\
\hline Maize silage & Low & $564.3 \mathrm{~b}$ & $385.8 \mathrm{~b}$ & $421.5 \mathrm{~b}$ & $7.01 \mathrm{~b}$ \\
& High & $598.1 \mathrm{a}$ & $402.6 \mathrm{a}$ & $509.5 \mathrm{a}$ & $8.39 \mathrm{a}$ \\
& SEM & 1.76 & 1.14 & 1.62 & 0.25 \\
Sorghum silage & Low & $539.0 \mathrm{~b}$ & $364.7 \mathrm{~b}$ & $374.7 \mathrm{~b}$ & $5.64 .0 \mathrm{~b}$ \\
& High & $598.5 \mathrm{a}$ & $404.9 \mathrm{a}$ & $422.0 \mathrm{a}$ & $6.38 .0 \mathrm{a}$ \\
& SEM & 2.50 & 1.26 & 3.49 & 0.53
\end{tabular}

$\mathrm{dDM}$ - digestible dry matter; $\mathrm{dNDF}$ - digestible neutral detergent fiber; $\mathrm{dOM}$ - digestible organic matter; ME - metabolizable energy; DM - dry matter; SEM - standard error of the mean.

Means in the same column with different letters differ significantly $(\mathrm{P}<0.05)$. 
Zhang and $\mathrm{Yu}$ (2015) evaluated the effects of the two levels of ensiling wet densities (500 and $600 \mathrm{~kg} / \mathrm{m}^{3}$ ) on the silage quality of Leymus chinensis silage. They found that lactic acid content was higher while the $\mathrm{pH}$ value, butyric acid, ammonium-N concentration, and the coliform bacteria were lower in high-density silage $\left(600 \mathrm{~kg} / \mathrm{m}^{3}\right)$. Savage et al. (2015) observed that lactic acid concentration was higher in maize silage ensiled at a rate of $240 \mathrm{~kg}$ of $\mathrm{DM} / \mathrm{m}^{3}$ dry density (5.55\%) than at $170 \mathrm{~kg}$ of $\mathrm{DM} / \mathrm{m}^{3}$ density $(4.40 \%)$. Rota et al. (2012) demonstrated the fermentation quality of maize silage $(256 \mathrm{~g} / \mathrm{kg})$ when ensiled at a rate of $246 \mathrm{~kg}$ $\mathrm{DM} / \mathrm{m}^{3}$ packing dry density for 110 days into 2-L micro silos. They reported that DM losses were $7.12 \%$, lactic acid was $93.9 \mathrm{~g} / \mathrm{kg} \mathrm{DM}$, acetic acid was $22 \mathrm{~g} / \mathrm{kg} \mathrm{DM}$, and ethanol was $7.49 \mathrm{~g} / \mathrm{kg}$ DM.

Test for the aerobic stability based on $\mathrm{CO}_{2}$ production showed that the presence of air during ensiling due to low packing density gave rise to poor post-storage quality in both silages. The set of deterioration process showed an increased level in $\mathrm{pH}$ values above five and a rise in yeast counts by seven $\log$ units (Vissers et al., 2007). These numbers were found in loosely packed silages (McDonald et al., 1991). The data from the stability tests reconfirm the findings of Tabacco et al. (2011) that tightly packed silages $\left(612 \mathrm{~kg} / \mathrm{m}^{3}\right)$ is more stable than loosely packed silages $\left(577 \mathrm{~kg} / \mathrm{m}^{3}\right)$. In that study, the spoiled silages also tended to show thermal instability. Further investigations by Windle and Kung Jr (2013) showed that that aerobically spoiled silage-based total mixed ration (TMR) contained $7.8 \log \mathrm{cfu}$ yeast $/ \mathrm{g}$ at the time of feed-out, whereas the fresh TMR contained $5 \log$ cfu yeast/g. Ruppel et al. (1995) and Muck et al. (2003) stated that greater silage density and feed-out rate together increase the time that silage is exposed to air without spoiling before removal from the silo.

The improved fermentation and aerobic stability of both silages may mirror what is observed in animal performance (McDonald et al., 1991; Gerlach et al., 2013; Windle and Kung Jr, 2013). Indeed, we observed that tightly packed silages had higher amount of degradable OM in the rumen and increased the energy content by 21 (maize silage) and $13 \%$ (sorghum silage), which indicates a conservation of nutrients (McDonald et al., 1991). Our results are in agreement with Flynn (1988), who demonstrated that in well-preserved and poorly preserved silages for cattle feed, the DM digestibility was 73.5 and $70.7 \%$, respectively. The effects of hygienic quality of silage on DM intake of dairy cows were previously examined (Wichert et al., 1998) and it has been seen that aerobic deterioration led to a decrease in DM intake of about 10-20\%. Feeding heifers with spoiled TMR resulted in lower DM intakes when compared with fresh TMR (Windle and Kung Jr, 2013). Aerobic deterioration can jeopardize the nutritive value of maize silage-based diets and can cause a reduction in feed intake of goats by $53 \%$ (Gerlach et al., 2013) and steers by $16 \%$ (Bolsen et al., 2002).

\section{Conclusions}

The more tightly packed silages enables better conservation of soluble carbohydrates, preserves silage proteins, and creates less change of structural carbohydrates. It increases post-storage stability aspects, which favor the acceptability and intake of silage that can enhance the animal performance.

\section{References}

AOAC - Association of Official Analytical Chemistry. 1990. Official methods of analysis. 15th ed. AOAC International, Arlington, VA.

Ashbell, G.; Weinberg, Z. G.; Azrieli, A.; Hen, Y. and Horevi, B. 1991. A simple system to study the aerobic deterioration of lactic acid in biological material. Canadian Agricultural Engineering 34:171-175.

Barker, S. B. and Summerson, W. H. 1941. The colorimetric determination of lactic acid in biological material. Journal of Biological Chemistry 138:535-554.

Bolsen, K. K.; Whitlock, L. A. and Uriarte-Archundia, M. E. 2002. Effect of surface spoilage on the nutritive value of maize silage diets. p.76-77. In: Proceedings of the 13th International Silage Conference, Auchinruive, Scotland.

Borreani, G. and Tabacco, E. 2009. Quantifying the extent of aerobic deterioration in corn bunker and pile silages at a farm level. p.321-322. In: Proceedings of the 15th International Silage Conference, Madison, WI.

Charley, R. 2008. Silage packing density. The Saskatchewan Stockgrower.

Driehuis, F. and Oude Elferink, S. J. 2000. The impact of the quality of silage on animal health and food safety: A review. Veterinary Quarterly 22:212-216.

Dubois, M.; Gilles, K. A.; Hamilton, J. K.; Rebers, P. A. and Smith, F. 1956. Colorimetric method for determination of sugars and related substances. Analytical Chemistry 28:350-356.

Flynn, A. V. 1988. Factors affecting the feeding value of silage. p.265-273. In: Recent advances in ruminant nutrition 2. Haresign, W. and Cole, D. J. A., eds. Butterworths, UK.

Gerlach, K.; Roß, F.; Weiß, K.; Büscher, W. and Südekum, K. H. 2013. Changes in maize silage fermentation products during aerobic deterioration and effects on dry matter intake by goats. Agricultural Food Science 22:168-181.

Holden, L. A. 1999. Comparison of methods of in vitro dry matter digestibility for ten feeds. Journal of Dairy Science 82:1791-1794.

Johnson, L. M.; Harrison, J. H.; Davidson, D.; Mahanna, W. C.; Shinners, K. J. and Linder, D. 2002. Corn silage management: Effects on maturity, inoculation and mechanical processing on pack density and aerobic stability. Journal of Dairy Science $85: 434-444$. 
Kung Jr, L. 2010. Aerobic stability of silage. In: Proceedings 2010 California Alfalfa and Forage Symposium and Corn/Cereal Silage Conference, Visalia, CA.

Losand, B. 2003. Maissilagequalitäten in der Milchkuhhaltung. MAIS, Nr. 1, 31. Jahrgang, 16-18.

McDonald, P.; Henderson, A. R. and Heron, S. J. E. 1991. The biochemistry of silage. 2nd ed. Chalcombe Publications, Marlow, Bucks, UK.

Menke, K. H. and Steingass, H. 1988. Estimation of the energetic feed value obtained from chemical analysis and gas production using rumen fluid. Animal Research Development 28:7-55.

Muck, R. E.; Holmes, B. J. and Savoie, P. 2004. Packing practice effects on density in bunker silos. ASAE Paper No. 041137. American Society of Agricultural Engineers, St. Joseph, MI.

Muck, R. E.; Moser, L. E. and Pitt, R. E. 2003. Postharvest plant factors affecting ensiling. p.251-304. In: Silage science and technology. Buxton, D. R.; Muck, R. E. and Harrison, J. H., eds. American Society of Agronomy, Madison, WI.

Rota, C.; Pirondini, M.; Malagutti, L. and Rapetti, L. 2012. Evaluation of fermentative parameters, aerobic stability and in vitro gas production of whole crop maize silage treated with a microbial inoculant containing Pediococcus pentosaceus and Lactobacillus plantarum. p.212-213. In: Proceedings of the 16th International Silage Conference, Finland.

Ruppel, K. A. 1992. Effect of bunker silo management on hay crop nutrient management. Thesis (M.Sc.). Cornell University, Ithaca, NY.

Ruppel, K. A.; Pitt, R. E.; Chase, L. E. and Galton, D. M. 1995. Bunker silo management and its relationship to forage preservation on dairy farms. Journal of Dairy Science 78:141-153.

Sharp, R.; Hooper, P. G. and Armstrong, D. G. 1994. The digestion of grass silages produced using inoculants of lactic acid bacteria. Grass and Forage Science 49:42-53.

Savage, R. M.; Smith, M. L.; Benjamim da Silva, E. and Kung-Jr, L. 2015. The effects of packing density and air stress on corn silage inoculated with Lactobacillus buchneri 40788. p.368-369. In: Proceedings of the 17 th International Silage Conference, Piracicaba, Brazil.
Savoie, P.; Muck, R. E. and Holmes, B. J. 2004. Laboratory assessment of bunker silo density part II: Whole-plant corn. Applied Engineering in Agriculture 20:165-171.

Tabacco, E.; Piano, S.; Cavallarin, L.; Bernardes, T. F. and Borreani, G. 2009. Clostridia spore formation during aerobic deterioration of maize and sorghum silages as influenced by Lactobacillus buchneri and Lactobacillus plantarum inoculants. Journal of Applied Microbiology 107:1632-1641.

Tabacco, E.; Righi, F.; Quarantelli, A. and Borreani, G. 2011. Dry matter and nutrition losses during aerobic deterioration of corn and sorghum silages as influenced by different lactic acid bacteria inocula. Journal of Dairy Science 94:1409-1419.

Van Soest, P. J.; Robertson, J. B. and Lewis, B. A. 1991. Methods for dietary fiber, neutral detergent fiber and nonstarch polysaccharides in relation to animal nutrition. Journal of Dairy Science 74:3583-3597.

Vissers, M. M. M.; Driehuis, F.; Te Giffel, M. C.; De Jong, P. and Lankveld, J. M. G. 2007. Concentrations of butyric acid bacteria spores in silage and relationships with aerobic deterioration. Journal of Dairy Science 90:928-936.

Weißbach, F. 2009. Correction of dry matter content of silages used as substrate for biogas production. p.483-484. In: Proceedings of the 15th International Silage Conference, Madison, WI.

Wichert, B.; Kienzle, E. and Bauer, J. 1998. Palatability and intake of silage in dairy cows, in relation to hygienic quality. Journal of Animal Physiology and Animal Nutrition 80:253-259.

Wilkinson, J. M. and Davies, D. R. 2013. The aerobic stability of silage: Key findings and recent developments. Grass and Forage Science 68:1-19.

Wilkinson, J. M. and Toivonen, M. I. 2003. World silage. Chalcombe Publications, Southampton, UK.

Windle, M. C. and Kung Jr, L. 2013. The effect of a feed additive on the feeding value of a silage-based TMR exposed to air. Journal of Dairy Science 91:16 (Abst.).

Zhang, Q. and Yu, Z. 2015. High ensiling density and lactic acid bacteria inoculant improved fermentation quality of leymus chinensis silage. p.390-391. In: Proceedings of the 17th International Silage Conference, Piracicaba, Brazil. 